\title{
An Evaluation of the Adsorptive Properties of Coconut Husk for Oil Spill Cleanup
}

Augustine Osamor Ifelebuegu and Zenebu Momoh

\begin{abstract}
The removal of vegetable oil and diesel fuel from seawater using waste coconut coir was investigated by batch adsorption experiments at varying sorbent doses and temperatures. Maximum adsorption capacities of 7231 and $6530 \mathrm{mg} / \mathrm{g}$ were achieved for the adsorption of vegetable oil and diesel fuel, respectively. The water adsorbency was relatively high at $6540 \mathrm{mg} / \mathrm{g}$ which is a limitation in its potential field application for oil spill cleanup. The maximum adsorption capacities improved significantly by up to $22 \%$ with a corresponding reduction in water adsorbency when coconut husk was impregnated with human hair. The adsorption kinetics followed a pseudo second order kinetic model and fitted to the Freundlich adsorption isotherm model. The sorption capacity was found to decrease with increasing temperatures. This work demonstrated that with adequate modifications to improve its hydrophobicity, coconut coir can potentially provide a low cost environmentally friendly adsorbent for oil spill cleanup.
\end{abstract}

Keywords-coconut coir, Adsorption capacity, oil spill

\section{Introduction}

Massive oil spills have often occurred as a result of exploration, production, storage and transportation of oil catalysed by the high demand for oil by the growing world population. When oil spill occurs, it has an adverse impact on the environment, economy, humans and biota [1,2], hence, the need for prompt cleanup after a spillage. One of the effective ways of achieving this is mechanical recovery by adsorbents. Adsorbents are insoluble materials or mixtures of materials applied to recover liquids by the mechanisms of absorption or adsorption. In absorption, molecules of the adsorbate penetrate the adsorbent while in adsorption, the molecules of the adsorbate bind to the outer surface of the adsorbent without penetrating into it $[3,4]$. Studies have shown that adsorption of oil by adsorbents is closely connected to their functional properties and surface morphology. Adsorbents can adsorb oil because of their ability to selectively remove resinous, sulphur containing compounds, unsaturated and polycyclic materials as well as organic residues of sulphuric acid and solvents from oil [5]. Important functional groups responsible for oil uptake include $\mathrm{O}-\mathrm{H}, \mathrm{N}-\mathrm{H}, \mathrm{C}-\mathrm{O}$ and $\mathrm{C}=\mathrm{O}$ groups [3]. The influence of surface morphology on adsorption can be seen in excellent adsorbents like kapok and populous seeds whose hollow structures coated with wax provide a large surface area for adsorption $[6,7,8]$.

Authors: A. O Ifelebuegu, Z. Momoh Coventry University

United Kingdom
Adsorbents are of three main types namely; natural inorganic sorbents, natural organic sorbents and synthetic sorbents.

Synthetic adsorbents are commonly used as commercial adsorbents for oil spill cleanup as they are hydrophobic and oleophilic. However, their cost and non-biodegradable nature has necessitated the search for alternatives that are cost effective, abundant in nature and eco-friendly. The use of coconut coir is investigated in this study with a view to evaluating their suitability as potential substitutes for synthetic adsorbents in booms, for oil spill cleanup.

Coconut coir is an agricultural waste obtained from the fibrous mesocarp layer of the coconut (Cocos nucifera L.) fruit [9]. It contains $38 \%$ cellulose, $28 \%$ hemicellulose and $32.8 \%$ lignin. Functional groups such as - $\mathrm{OH}$ and fibre carbonaceous $\mathrm{C}_{\mathrm{x}} \mathrm{OH}$ present on its surface are dissociated at specific $\mathrm{pH}$ values and facilitate the uptake of positively charged metal ions from aqueous solution. Its lignin content plays a vital role its capacity to adsorb organic substances from aqueous solutions [10].

\section{Materials and Methods}

\section{A. Materials}

The coconut husk used in this experiment was purchased from the local store in Coventry. It was then pulverised, washed and dried in the oven. Human hair used was also collected from a local barbing salon. The human hair was of African origin, it was washed with detergent and hot water and dried prior to use. Samples of the dried adsorbents are shown in figures 1 a $\&$ b. The vegetable oil was purchased from Sainsbury Supermarket, the diesel fuel from Esso, Coventry, UK. Artificial sea water was prepared as has been previously described in Kester et al. 1967 [11].

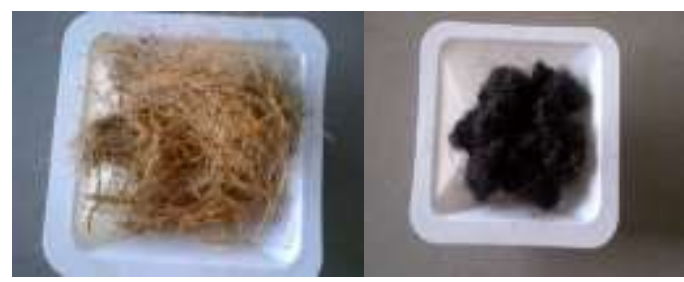

a b

Figure 1(a) coconut coir (b) Human hair 
Proc. of the Intl. Conf. on Advances in Applied science and Environmental Technology - ASET 2015.

Copyright ( $)$ Institute of Research Engineers and Doctors, USA .All rights reserved.

ISBN: 978-1-63248-040-8 doi: 10.15224/ 978-1-63248-040-8- 38

\section{B. Batch Experiments}

Adsorption experiments were conducted in seawater. $20 \mathrm{~g}$ of vegetable oil and diesel fuel were poured into separate $500 \mathrm{ml}$ conical flask with $200 \mathrm{ml}$ of sea water. Varying amounts of the sorbents were added with a 60 mins contact time following the ASTM F 726-99 standard methods for testing oil spill sorbents [12]. Water adsorbency was also measured following the same method. Oil concentrations were measured based on US-EPA method 1664 [13]. Oil adsorption capacities (mg/g) were obtained from the following equation: Sorption Capacity $=\frac{X_{0}-X_{S}}{X_{S}}$

Where $\mathrm{X}_{\mathrm{o}}$ is the total mass of wet sorbent after oil adsorption and Xs is the mass of the adsorbent before adsorption. All experiments were conducted at room temperature $\left(25^{\circ} \mathrm{C} \pm\right.$ $2^{0} \mathrm{C}$ ) and carried out in triplicate with the average value and standard deviation (SD) calculated. Sample data with SD greater than $10 \%$ were rejected with a re-run of the test carried out.

\section{Results and Discussions}

\section{A. Effect of Contact Time on Adsorption Capacity of Coconut Coir}

The effects of contact time on the adsorption capacity of coconut coir for vegetable oil and diesel fuel and are illustrated in Figure 2. It can be seen that there was a rapid increase in the retention of vegetable oil and diesel fuel in the first 5 minutes and thereafter proceeded at a slower rate and finally attained equilibrium at about 60 minutes. The initial high retention rate of the adsorbates can be attributed to the existence of bare active sites on coconut coir. As portions of these sites got occupied with molecules of diesel fuel and vegetable with increasing contact time, the adsorption rate became slower until the $60^{\text {th }}$ minute when there was no more significant adsorption due to the saturation of the surfaces of coconut husk and hence an equilibrium between adsorption and desorption processes [8].

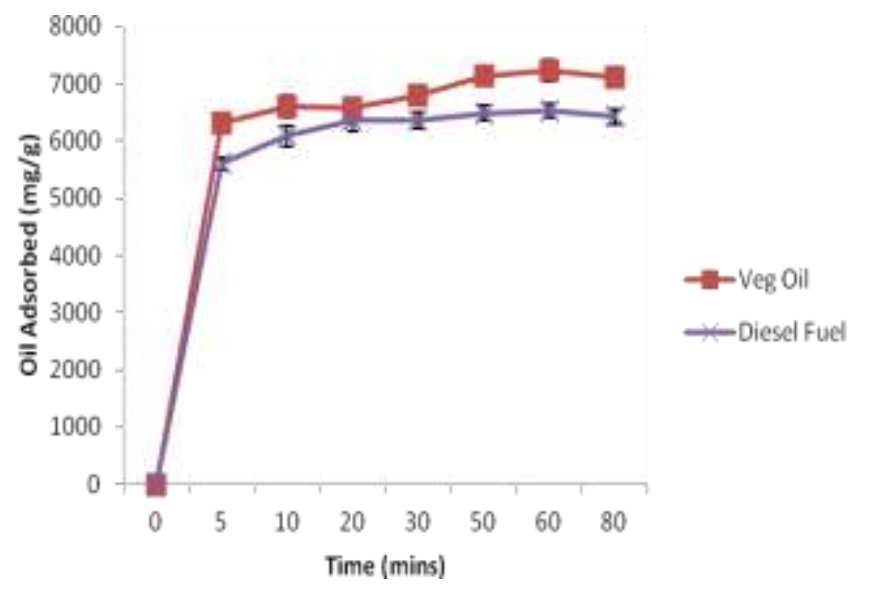

Figure 2. Adsorption Rate of coconut coir in vegetable oil and diesel fuel at temperature $250 \mathrm{C} \pm 2^{\circ} \mathrm{C}$. The bars represent standard deviation of the mean.

\section{B. Oil/Water Adsorbency of Coconut Coir}

The oil and water adsorbency for coconut husk and varying combination of coconut husk and human hair are shown in the figure 3. It can be seen that coconut husk has a comparatively good oil adsorption properties but also has a high water adsorbency which could be a limiting factor in potential field application. It can also be seen that the oil adsorbency increased significantly with decreased water adsorbency when modified by blending it with human hair. The increased oil adsorbency and lower water adsorbency of the coconut coir impregnated with human hair are due to the higher oleophilicity and hydrophobicity of human hair. A ratio of adsorbency to water adsorbency greater than one is often considered a good characteristic for oil adsorbents. This ratio was greater than one fpr vegetable oil adsorption to coconut coir but less than one for diesel fuel. It was however, significantly improved above one for both vegetable oil and diesel fuel when coconut coir was impregnated with human hair. Table 1 shows the reported adsorption capacity for other similar adsorbents and how coconut husk compares. It can be seen it compares favorably with some alternative adsorbents. A drawback to its use in oil spill cleanup is its high water absorbency which can be significantly reduced with increase in oil adsorbency by modification, to increase its oleophilicity and hydrophobicity.

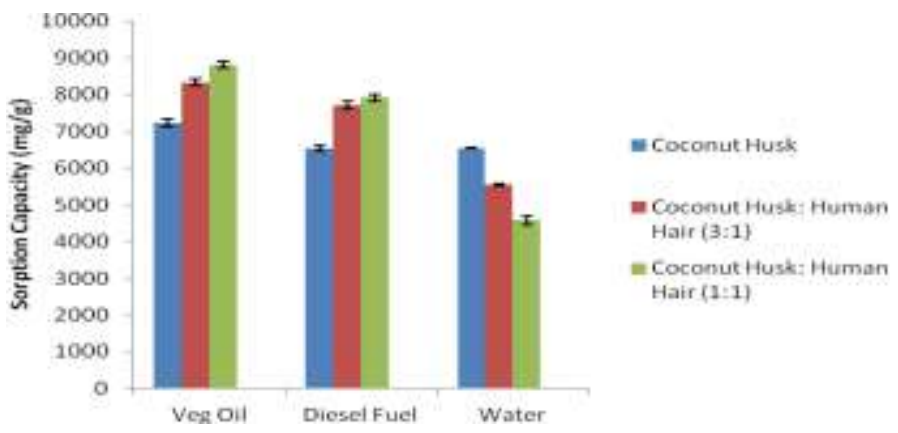

Figure 3. Adsorption capacities of coconut coir and coconut coil human hair blends, in vegetable oil and diesel fuel at $25^{\circ} \mathrm{C}$ $\pm 2^{0} \mathrm{C}$. The bars represent standard deviation of the mean.

Table 1: Types of adsorbents, adsorbates and their adsorption capacities

\begin{tabular}{|l|l|l|l|}
\hline $\begin{array}{l}\text { Types of } \\
\text { adsorbent }\end{array}$ & Adsorbate & $\begin{array}{l}\text { Adsorption } \\
\text { capacity } \\
(\mathrm{mg} / \mathrm{g})\end{array}$ & Reference \\
\hline $\begin{array}{l}\text { Activated sugar } \\
\text { bagasse }\end{array}$ & Machine oil & 20,000 & {$[15]$} \\
\hline Acetylated banana & Machine oil & 18,012 & {$[16]$} \\
\hline
\end{tabular}


Proc. of the Intl. Conf. on Advances in Applied science and Environmental Technology - ASET 2015.

Copyright (C) Institute of Research Engineers and Doctors, USA .All rights reserved.

ISBN: 978-1-63248-040-8 doi: 10.15224/ 978-1-63248-040-8- 38

\begin{tabular}{|l|l|l|l|}
\hline $\begin{array}{l}\text { Polypropylene } \\
\text { (commercial } \\
\text { sorbent) }\end{array}$ & Crude oil & $9100-10,000$ & {$[17]$} \\
\hline Organoclay & Diesel & 7200 & {$[18]$} \\
\hline Treated sludge & Crude oil & 2000 & {$[10]$} \\
\hline $\begin{array}{l}\text { Modified oil palm } \\
\text { leaves }\end{array}$ & $\begin{array}{l}\text { Vegetable } \\
\text { oil }\end{array}$ & 646 & {$[19]$} \\
\hline Human hair & $\begin{array}{l}\text { Vegetable } \\
\text { oil } \\
\text { Crude oil } \\
\text { Diesel fuel }\end{array}$ & $\begin{array}{l}9300 \\
8100\end{array}$ & {$[20]$} \\
\hline Coconut coir & $\begin{array}{l}\text { Vegetable } \\
\text { oil } \\
\text { Diesel fuel }\end{array}$ & 7231 & This study \\
\hline $\begin{array}{l}\text { Coconut coir and } \\
\text { human hair (3:1) }\end{array}$ & $\begin{array}{l}\text { Vegetable } \\
\text { oil } \\
\text { Diesel fuel }\end{array}$ & 8333 & 7705 \\
\hline $\begin{array}{l}\text { Coconut coir and } \\
\text { human hair (1:1) }\end{array}$ & $\begin{array}{l}\text { Vegetable } \\
\text { oil } \\
\text { Diesel fuel }\end{array}$ & 8814 & This study \\
\hline
\end{tabular}

\section{Adsorption Kinetics and Isotherms}

The adsorption kinetics was investigated for coconut coir by using the pseudo-first order and pseudo-second order adsorption models as proposed by Lagergren, 1898 [21] and can be expressed linearly as:

$$
\begin{aligned}
& \log (\mathrm{Ce}-\mathrm{Ct})=\log \mathrm{Ce}-\frac{\mathrm{k} 1}{2.303} \\
& \mathrm{t} / \mathrm{C}_{\mathrm{t}}=1 / \mathrm{k} 2 * \mathrm{C}^{2}+\mathrm{t} / \mathrm{C}_{\mathrm{e}}
\end{aligned}
$$

Pseudo-first order plot of Log (Ce-Ct) against t should give a linear relationship from which $\mathrm{k}_{1}$ in $\left(\mathrm{min}^{-1}\right)$ can be calculated from the slope of the graph. A plot of $\mathrm{t} / \mathrm{Ct}$ will give a rate constant $\mathrm{k}_{2}\left(\mathrm{mg} \mathrm{g}^{-1} \mathrm{~min}^{-1}\right)$ for pseudo-second order kinetics. Table 2 presents the constant values and correlation coefficients $\mathrm{R}^{2}$ of both pseudo-first order and pseudo-second order kinetic models for adsorption of vegetable oil and diesel fuel onto coconut coir. The kinetic plots showed a good fit of sorption equilibrium data with respect to pseudo-second order on the basis of the correlation coefficient. This suggests the possibility of chemisorption as the rate controlling step.

Table 2. Result obtained from pseudo first order and pseudo second order kinetic modeling of the adsorption of diesel and vegetable oil by coconut coir

\begin{tabular}{|l|c|c|c|c|}
\hline \multirow{2}{*}{} & \multicolumn{2}{|c|}{ Pseudo-first order } & \multicolumn{2}{c|}{$\begin{array}{c}\text { Pseudo-second } \\
\text { order }\end{array}$} \\
\cline { 2 - 5 } & $\mathrm{R}^{2}$ & $\mathrm{~K}_{1}$ & $\mathrm{R}^{2}$ & $\mathrm{~K}_{2}$ \\
\hline Diesel oil & 0.349 & 0.024 & 0.984 & 0.034 \\
\hline Vegetable oil & 0.591 & 0.024 & 0.983 & 0.005 \\
\hline
\end{tabular}

The equilibrium data obtained in the isotherm study was analysed using the Langmuir and Freundlich adsorption isotherm models. The linear form of the Langmuir isotherm is expressed in equation 4 as:

$\frac{1}{X / M}=\frac{1}{b}+\frac{1}{a b} \times \frac{1}{C_{\theta}}$

where:

$\mathrm{X}$ - the mass of adsorbate

$\mathrm{M}$ - the mass of adsorbent

$\mathrm{C}_{\mathrm{e}}$ - the concentration of solute remaining at equilibrium in $\mathrm{mg} / \mathrm{l}$

$\mathrm{a}, \mathrm{b}$ - the constants. $\mathrm{a}$ is coefficient and $\mathrm{b}$ is the amount of

adsorbate needed to form a complete monolayer on the adsorbent surface and so increases with molecular size. A plot of $(1 /(\mathrm{X} / \mathrm{M}))$ against $\left(1 / \mathrm{C}_{\mathrm{e}}\right)$ gave a straight line.

Also the linearised form of the Fruendlich isotherm is expressed in equation 5 :

$\log \frac{X}{M}=\log k_{f}+\frac{1}{n} \log C_{e}$

where:

$\mathrm{X}$ - the mass of adsorbate

$\mathrm{M}$ - the mass of adsorbent

$\mathrm{C}_{\mathrm{e}}$ - the concentration of solute remaining at equilibrium in $\mathrm{mg} / \mathrm{l}$

$\mathrm{k}_{\mathrm{f}}$ and $\mathrm{n}-$ constants derived from the adsorption isotherm by plotting $(\mathrm{X} / \mathrm{M})$ against $\mathrm{C}_{\mathrm{e}}$ on $\log$-log paper which produces a straight line with a slope $1 / n$ while the $y$ intercept is $k_{f}$.

The results of the isotherm study showed a good fit of the Freundlich model, indicating that sorption of the oils onto coconut coir occurred on heterogeneous sites with nonuniform distribution of energy level rather than on homogenous sites.

\section{Effect of Ttemperature on Adsorption of Crude Oil by Coconut Coir}

The effect of temperature on the uptake efficiency of crude oil by coconut coir was investigated at varying temperatures of $18,28,38$ and $48^{\circ} \mathrm{C}$.The results of the adsorption capacities at varying temperatures is illustrated in figure 4 . It can be seen that the oil retention efficiency by coconut husk decreased with increasing temperatures. The decrease in adsorption of oil from aqueous media as the temperature of the media increases may be due to the fact that its solubility in water increases, its viscosity decreases making it drain off sorbent's surface easily. In addition, its Brownian motion increases, hence increasing the energy required to bind the oil to the surface of the coconut coir $[22,23]$. 
Proc. of the Intl. Conf. on Advances in Applied science and Environmental Technology - ASET 2015.

Copyright $(\odot$ Institute of Research Engineers and Doctors, USA .All rights reserved.

ISBN: 978-1-63248-040-8 doi: 10.15224/ 978-1-63248-040-8- 38

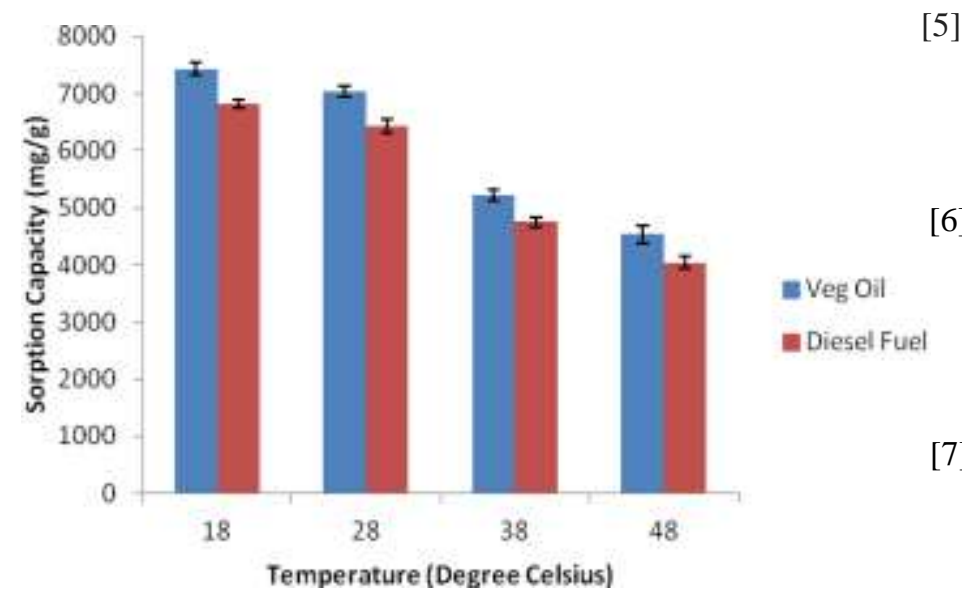

Figure 4. Effect of temperature on the sorption capacity of coconut coir. The bars represent standard deviation of the mean.

\section{Iv. Conclusion}

The adsorption capacity of coconut coir was evaluated to determine its applicability as an oil spill adsorbent. Adsorption capacities of 7231 and $6530 \mathrm{mg} / \mathrm{g}$ were achieved for pure coconut coir for the adsorption of vegetable oil and diesel fuel, respectively. The ratio of oil adsorbency to water adsorbency was greater than 1 for vegetable oil and less than 1 for diesel fuel. With the impregnation of coconut coir with human hair, water adsorbency was reduced and adsorption capacities for vegetable oil and diesel fuel increased to 8814 and $7916 \mathrm{mg} / \mathrm{g}$, respectively. The adsorption capacities for both vegetable and diesel fuel were inversely related to temperature. The adsorption kinetic followed a pseudo-second order kinetic model. With the modification of coconut coir to reduce its water adsorbency, it could potentially be used as a low- cost adsorbent for the cleanup of oil spills in oily water.

\section{References}

[1] J. Chen, and M. S. Denison, "The Deepwater Horizon oil spill: environmental fate of the oil and the toxicological effects on marine organism," Journal of Young Investigators, vol. 21, pp. 84-95, 2011.

G. M. Solomon and S. Janssen, "Health effects of the gulf oil spill," JAMA: The Journal of the American Medical Association, Vol. 304, pp. 1118-1119, 2010.

[3] A. L. Ahmad, S. Sumathi, and B. H. Hameed, "Adsorption of residue oil from palm oil mill effluent using powder and flake chitosan: equilibrium and kinetic," Water Research, vol. 39, pp. 2483-94, 2005.

[4] R. Wahi, L. A. Chuah, T. S. Y Choong, Z. Ngaini, and M. M. Nourouzi, "'Oil removal from aqueous state by natural fibrous sorbent: an overview," Separation and Purification Technology, vol.113, pp. 51-63, 2013.
[5] R. R Mohammed, I. A. Ibrahim, A. H. Taha and G. McKay, "Waste lubricating oil treatment by extraction and adsorption," Chemical Engineering Journal, vol. 220, pp. 343-351, 2013.

[6] M.Abdullah, A. U. Rahmah and Z. Man, "Physicochemical and sorption characteristics of Malaysian Ceiba pentandra (L.) Gaertn. as a natural oil sorbent," Journal of Hazardous Materials, vol. 177, pp. 683-691, 2010.

T. Lim, and X. Huang, "Evaluation of kapok (Ceiba Pentandra (L.) Gaertn.) as a natural hollow hydrophobic-oleophilic fibrous sorbent for oil spill cleanup," Chemosphere, vol. 66, pp. 955-963, 2007.

R. Rengasamy, D., Das and C. Praba Karan, (2011) "Study of oil sorption behavior of filled and structured fiber assemblies made from polypropylene, kapok and milkweed," Journal of Hazardous Materials, vol. 186, pp. 526-532, 2011.

[9] Suhas, P. J. M Carrott and M. M. L. Ribeiro Carrott, "Lignin - from natural adsorbent to activated carbon: a review," Bioresource Technology, vol. 98, pp. 2301-2312, 2007.

[10] S. A. Sayed and A. M. Zayed, "Investigation of the effectiveness of some adsorbent materials in oil spill clean-ups," Desalination, vol. 194, pp. 90-100, 2006.

[11] D.R. Kester, I.W Duedall, D.N. Connors and R.M. Pytkowicz, "Preparation of artificial seawater," Journal of Limnology and Oceanography, vol. 12, pp. 176-179, 1967.

[12] ASTM 1998c, F726-99: standard test method for sorbent performance of adsorbents in: Annual Book of ASTM Standards, ASTM committee on Standards, West Conshohocken, PA, 1998.

[13] US-EPA (1999) Method 1664, revision A: N-hexane extractable material (HEM; oil and grease) and silica gel treated N-hexane extractable material (SGT-HEM; non-polar material) by extraction and gravimetry. United States Environmental Protection Agency, Cincinnati, 1998.

[14] X. LI, C. Zhang and J. Liu, "Adsorption of oil from waste water by coal: characteristics and mechanism," Mining Science and Technology (China), vol. 20, pp. 778-781, 2010.

[15] X Sun, R.Sun, and J. Sun, “Acetylation of sugarcane gagasse using NBS as a catalyst under mild reaction conditions for the production of oil sorption-active materials," Bioresource Technology, vol. 95, pp. 343350, 2004. 
[16] M. D. Teli,. and S. P. Valia, "Acetylation of banana fibre to improve oil absorbency," Carbohydrate Polymers, vol. 92, pp.328-333, 2013.

[17] Q. F. Wei, R. R. Mather, A. F. Fotheringham and R. D. Yang, "Evaluation of nonwoven polypropylene oil sorbents in marine oil-spill recovery," Marine Pollution Bulletin, 46, pp. 780-783, 2003.

[18] O.Carmody, R. Frost, Y. Xi and S. Kokot, "Adsorption of hydrocarbons on organo-claysimplications for oil spill remediation," Journal of Colloid and Interface Science, vol. 305, pp. 17-24, 2007.

[19] S. Sidik, A. Jalil, S. Triwahyono, S. Adam, M. Satar, and B. Hameed, (2012) 'Modified oil palm leaves adsorbent with enhanced hydrophobicity for crude oil removal," Chemical Engineering Journal, vol. 203, pp. 9-18, 2012.

[20] A. O. Ifelebuegu, T. V. Nguyen, P. Ukotije-Ikwut, Z. Momoh "Liquid-phase sorption characteristics of human hair as a natural oil spill sorbent," Journal of Environmental Chemical Engineering, (in press).

[21] Langergren, S., and Svenska, K. (1898). About the theory of so-called adsorption of soluble substances," Kungliga Svenska Vetenskapsakademiens Handlingar, vo. 24 pp. 1-39, 1898.

[22] K. Amela, M. A. Hassen, and D. Kerroum, (2012) 'Isotherm and kinetics study of biosorption of cationic dye onto banana peel," Energy Procedia, vol. 19, pp. 286-295, 2012.

[23] I. A. Okoro, D. Okwu and U. Emeka, "Sorption Kinetics and intra particulate diffusivity of crude oil on kenaf (Hibiscus Cannabinus L.) plant part," Journal of Engineering and Applied Science, vol. 2, pp. 170-173, 2007. 